\title{
高速液体クロマトグラフィーによる海洋環境試料中の 核酸塩基類の定量
}

門谷茂®*，多田 邦尚**，垧市 友利*

（1986 年 3 月 4 日受理）

\begin{abstract}
生物の生体構成成分として重要な化学物質である核酸塩基類を，海洋環境中の種々の試料から抽出 し，定量する方法について検驸した。本研究では，陽イオン交換樹脂を用いた HPLGによって 6 種類 の核酸塩基類，すなわちウラシル，チミン，シトシン，グアニン，フデニン，ヒボキサンチンを分離・ 定量することを試みた。この方法を用いて, 海水中の懸濁粒子とたい積物中の核酸塩基類を, 此較的簡 単な操作でかつ短時間で分析・定量することができた，その結果，瀬戸内海播磨灘の慜濁粒子中の核酸 塩基総量は $0.3 \sim 9.3 \mu \mathrm{g} / \mathrm{l}$ であり，海底たい積物では 4〜54 $\mu \mathrm{g} / \mathrm{g}$ の值が得られた。
\end{abstract}

\section{1 緒 言}

核酸塩基類は，生物のデオキシリボ核酸（DNA），リ ボ核酸(RNA) の構成成分であると共に，エネルギー代 謝やその他の生化学過程に関与しており, 生物にとって は極めて重要な化学物質である. 従って, これらの物質 の環境中での挙動を明らかにすることは, 生物地球化学: 的に大きな意義があると考兄らる。

1959 年に Beleser によって核酸塩基類の海水中での 存在が確認された が，以後その環境中での挙動に関す る研究は非常に少なく、わずかに岡市2)が瀬戸内海の底 泥間げき水中からウラシル，チミンを同定している報告

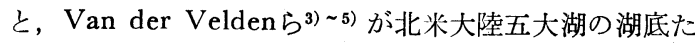
い積物について 7 種類の核酸塩基類の定性・定量を試み た報告があるのみである．

そこで本研究では核酸塩基類の海洋環境中に括ける挙 動を調べるために，まず海洋に存在する種々の粒子状物 質について HPLG を用い，核酸塩基類を簡便でかつ迅 速に抽出・分析する方法を倹討した.

\section{2 試薬，装置及び試料}

\section{1 試 薬}

7 種の核酸塩基類の標準溶液は, 和光純薬工業の標品 を用い調製した。 その他の試薬も，すべて同社の特級の ものを用い調製した。

* 香川大学農学部 : 761-07 香川県木田郡三木町池戸

** 現在 北海道大学水産学部北洋水産研究施設 : 041 北海道函館市港町 3-1-1

\subsection{HPLC}

カラムは日本分光 Jasco Fine Gel SG-120を, ポン プは日本分光 $\mathrm{BIP}-1$ を, 検出器は島津紫外分光光度計 検出器 SPD-2A を, 又定量には積分計, 鼠津クロマト パック $\mathrm{C}-\mathrm{E} 1 \mathrm{~B}$ を使用した。

\section{3 試 料}

核酸塩基類を分析する試料として，たい積物粒子及び 海水中の懸濁粒子の 2 種類を用いた，以下に，その調製 法を記す。

海底たい積物：瀬戸内海播磨灘中央部の $34^{\circ} 29^{\prime} \mathrm{N}$, $134^{\circ} 33^{\prime} \mathrm{E}$, 水深 $42 \mathrm{~m}$ の定点より, 柱状採泥器を用いて

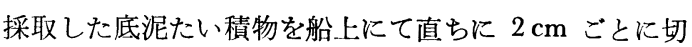
断し， $-20^{\circ} \mathrm{C}$ で涷結保存した。これを凍結乾燥後, め のら乳鉢で十分混合粉碎後, 試料とした。

愳濁粒子：播磨灘北部の $34^{\circ} 45^{\prime} \mathrm{N}, 134^{\circ} 30^{\prime} \mathrm{E}$, 水深約 $16 \mathrm{~m}$ の定点より, バンドーン型採水器を用いて採取し た各層 $(0,2,5,10,14 \mathrm{~m})$ の海水を, あらかじめ $450^{\circ} \mathrm{C}$ で 2 時間燃焼処理してある Whatman GF/C フィルタ 一により沪別して懸濁粒子を集めた。試料は，分析時ま で $-20^{\circ} \mathrm{C}$ で涷結保存した。 これを凍結乾燥したものを 分析試料とした.

\section{2 実験}

\section{1 抽出・精製操作}

3.1.1 海底たい積物 操作の概要を Fig. 1 亿示し た. 乾燥たい積物試料 $5 \sim 6 \mathrm{~g}$ を内容量 $100 \mathrm{ml}$ のねじ 


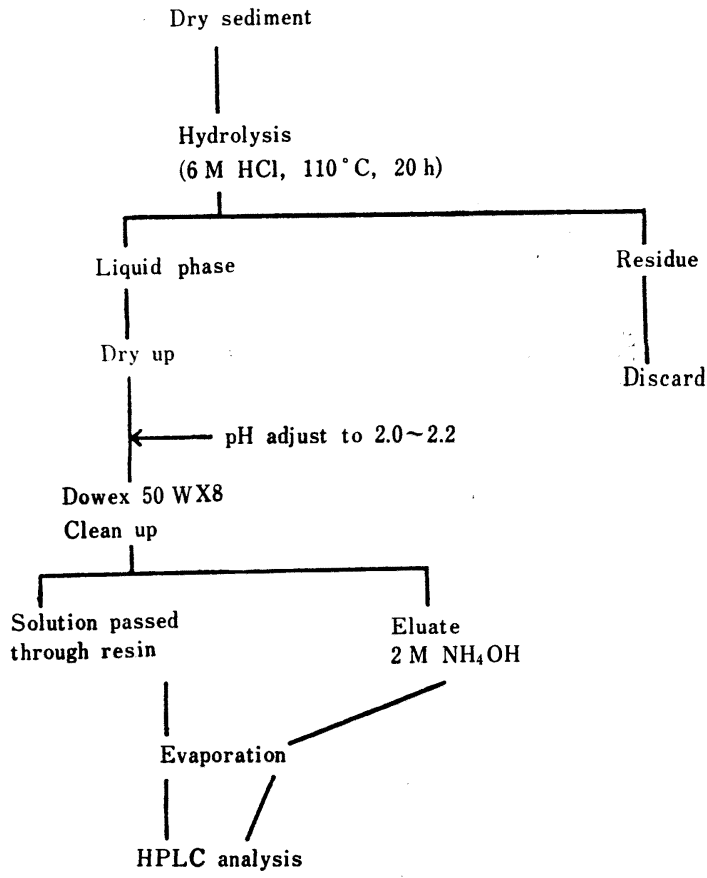

Fig. 1 Flow diagram for the isolation of purines and pyrimidines in sediment
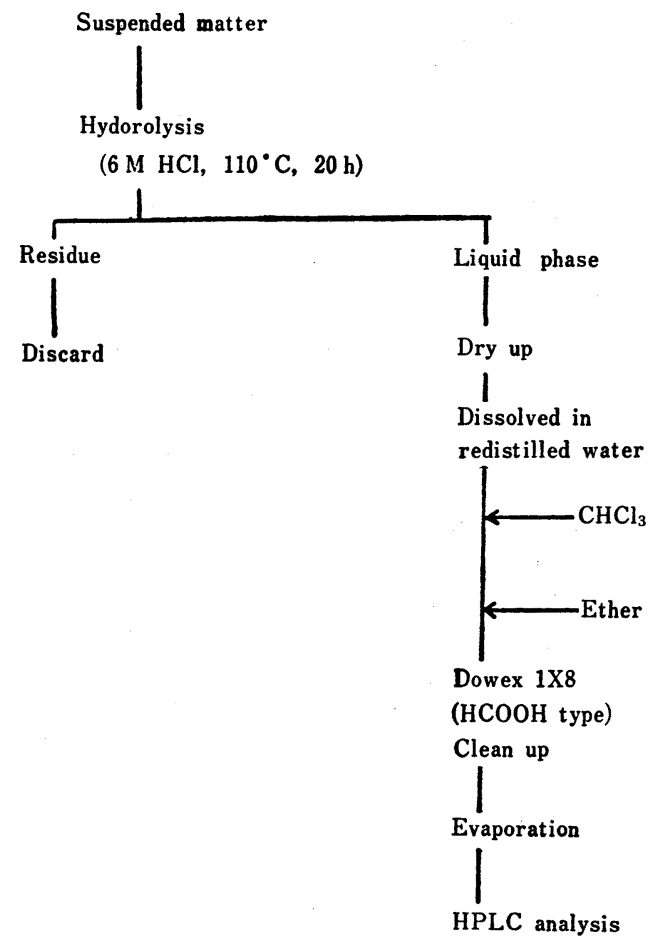

Fig. 2 Flow diagram for the isolation of purines and pyrimidines from suspended matter in seawater
口付きガラス瓶に精ひょうし，試料 $1 \mathrm{~g}$ にさ $6 \mathrm{M}$ 塩 酸 $10 \mathrm{ml}$ を加えて窒素を 10 分間通気後, 油浴を用い て $110^{\circ} \mathrm{C}$ で 20 時間加水分解した. これを前述した 方法で処理した Whatman GF/C フィルターで沪別 し, 汇液を $\mathrm{pH} 2.0 \sim 2.2$ に調整した後イオン交換樹脂 Dowex 50WX8 (100 200 メッシュ, $\mathrm{H}^{+}$型) カラム $(\phi 1 \mathrm{~cm} \times 20 \mathrm{~cm})$ を用い，色素などを除去した。 この 条件では, ウラシル，チミンは吸着されず，他の塩基類 は吸着される，試料溶液をカラムに通した後，樹脂の 5 倍量の再蒸留水で水洗し, この洗液を通過液に加えて, これをウラシル，チミン分析用試料とした．他の塩基類 は, 樹脂量の 5 倍量の $2 \mathrm{M}$ 水酸化アンモ二ウム水溶液 で溶出させるが，これにはヒポキサンチン，シトシン， グアニンが含まれる。これらの通過液及び溶出液は合併 した後, $45^{\circ} \mathrm{C}$ 以下でロータリーエバポレーターを用い て, 減圧乾国の後, 適当量の $0.05 \mathrm{M}$ 炭酸リチウム溶液 で溶解し, HPLC 分析に供した.

3.1.2 㥎濁粒子 操作の概要を Fig. 2 に示した。 Whatman GF/Cフィルター上に集めた䀣濁粒子試料は, 沪紙ごと内容量 $100 \mathrm{ml}$ の社じ口付きガラス瓶に入れ, 約 $50 \mathrm{ml}$ の $6 \mathrm{M}$ 塩酸を加え, たい積物試料と同様の 条件 で加水分解した. この加水分解溶液は減圧乾固の後, 再 び少量の再蒸留水に溶解させた. 次に, この水溶液を分 液漏斗に採り，等量のクロロホルムで 2 回，エーテルで 1 回脱脂後，pH 5 6 に調整し，イオン交換樹脂 Dowex 1X8（100〜200 メッシュ，Cl- 型をギ酸型に調 整) のカラム $(\phi 1 \mathrm{~cm} \times 5 \mathrm{~cm})$ を用いて脱塩処理した. 核酸塩基類は，この条件では吸着されない6)。 そこで試 料溶液をカラムに通した後，樹脂量の約 50 倍量の再蒸 留水でカラムを洗浄し，この洗液を減圧乾固した。乾固 した武料は適当量の $0.05 \mathrm{M}$ 炭酸りチウム溶液に溶解さ せ, HPLC 分析に供した.

\section{2 分析・定量操作}

前述の方法で調製した試料を，陽イオン交換樹脂 (Jasco Fine Gel SC-120) を用いた HPLC で分析し た. カラムには恒温水を循環させるガラス製外筒を装備 し，カラム温度を $60^{\circ} \mathrm{C}$ になるように調整した．移動相 には, $12 \mathrm{M}$ 塩酸を用いて $\mathrm{pH} 8.7$ に調整した $0.05 \mathrm{M}$ 炭酸リチウム溶液を使用した。測定の際, 試料溶液 8 $10 \mu \mathrm{l}$ を分析に供し，検出は $254 \mathrm{~nm}$ の吸光度，同定は 標準物質のピーク保持時間との比較により行った. 又定 量は，ピーク面積法により積分計を用いて行った。これ らの分析条件の詳細を Fig. 3 に示した. 


\section{4 結果}

\subsection{HPLC}

HPLG のクロマトグラムの一例を Fig. 3 に示した. Fig. 3 は注入量が各々 $150 \mathrm{pmol}$ になるように混合した 6 種類の核酸塩基類の標準溶液のクロマトグラムと，た い積物を分析したクロマトグラムである．6種の核酸塩 基は互いによく分離しており，ウラシル，七ポキサンチ ソ, チミン, シトシン, グアニン, アデニンの順で溶出 し, 約 25 分で分析を終了した.

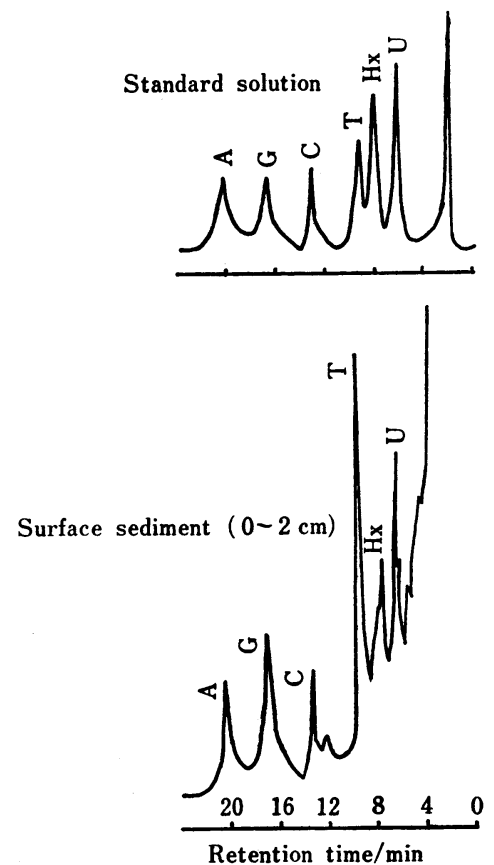

Fig. 3 Cation-exchange HPLG of a standard sclution of purines and pyrimidines and a sediment sample

A : adenine, $\mathrm{G}$ : guanine, $\mathrm{C}$ : cytosine, $\mathrm{T}$ : thymine, $\mathrm{Hx}$ : hypoxanthine, $\mathrm{U}:$ uracil; $\mathrm{HP}$ LC condition - Column : $4.6 \times 250 \mathrm{~mm}$; ion exchange resin : Jasco Fine Gel SC-120; temp. : $60^{\circ} \mathrm{C}$; solvent : $0.05 \mathrm{M} \mathrm{Li}_{2} \mathrm{CO}_{3}+\mathrm{HCl} \quad(\mathrm{pH}$ 8.7 ); rate of elution : $0.5 \mathrm{ml} / \mathrm{min}$

\section{2 検量線}

市販の標準物質を用いて，検量線を作成した。6 種類 の核酸塩基類標準品による添加量とピーク面積の関係 を Fig. 4 に示した。両者の間には, $50 \mathrm{pmol}$ から 300 pmol まで，良い直線関係が得られた。

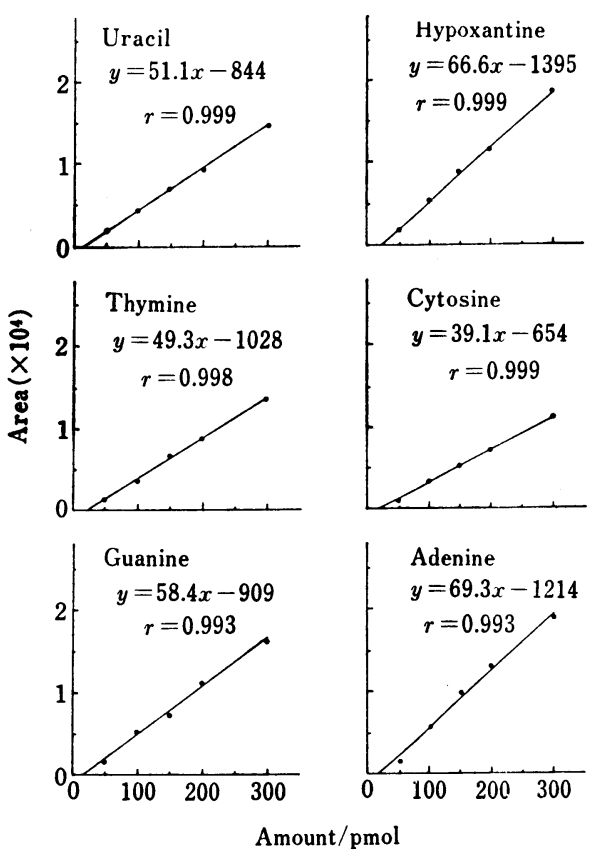

Fig. 4 Galibration curves for the determination of purines and pyrimidines

\section{3 綝り返し分析精度}

6 種の 核酸塩基類標準品を各々 $150 \mathrm{pmol}, 9$ 回, HPLC に注入し，その相対標準偏差を求め，結果を Table 1 に示した。相対標準偏差は, アデニン (6.5\%) を除いて各塩基とも5\% 以下の值が得られ，定量性に は問題がないことが分かった.

Table 1 Relative standard deviation in the determination of purines and pyrimidines

\begin{tabular}{lc}
\hline & R.S.D., \% \\
\hline Uracil & 3.0 \\
Hypoxanthine & 3.8 \\
Thymine & 3.2 \\
Cytosine & 4.4 \\
Guanine & 3.6 \\
Adenine & 6.5 \\
\hline
\end{tabular}

R.S.D. : relative standard deviation $(n=9)$; Sample amount : $150 \mathrm{pmol}$ each

\section{4 回収率}

$3 \cdot 1$ で述べた加水分解, 脱脂操作及びイオン交換樹脂 による精製過程での核酸塩基類の平均回収率は,それぞ れ 100\%,87\%,92\%であり定量的に回収されることが 分かった. 


\section{5 懸濁粒子及び海底たい積物の分析結果}

海水中の憅濁粒子及び海底たい積物の分析結果の一例 を Fig. 5, Fig. 6 に示した.

㲘濁粒子中の核酸塩基総量は $0.3 \sim 9.3 \mu \mathrm{g} / 1$ であり, 現場の Chl a 量とよく似た鉛直分布を示した。

柱状に採取したたい積物試料中の核酸塩基総量は，表 層では約 $54 \mu \mathrm{g} / \mathrm{g}$ であったが $0 \sim 9 \mathrm{~cm}$ の間に著しく減 少し，次いで下層に向かって指数関数的に減少してい

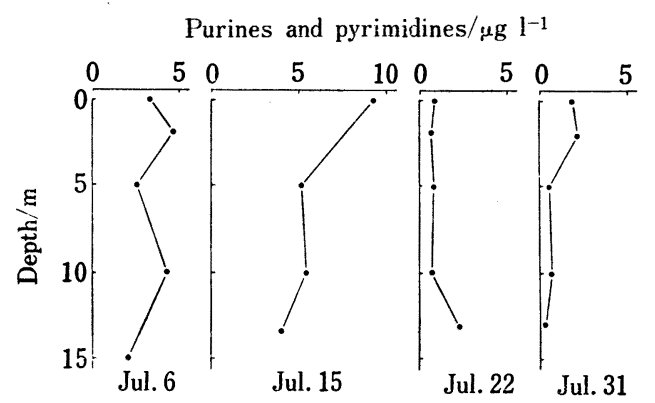

Fig. 5 Vertical distribution of purines and pyrimidines in suspended matter in seawater at summer period

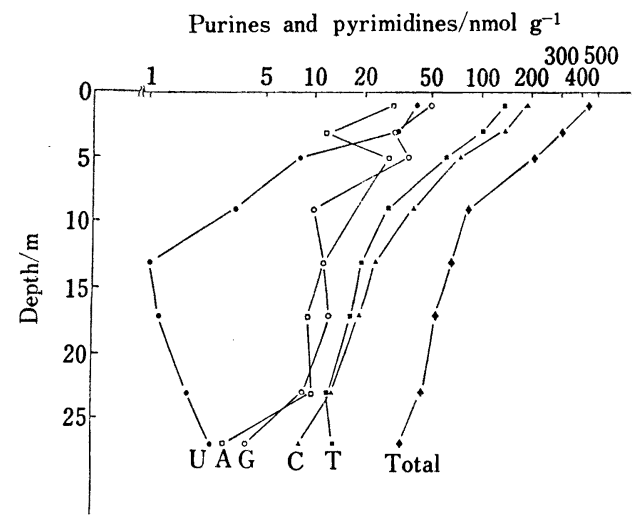

Fig. 6 Vertical distribution of purines and pyrimidines in sediment sample $\mathrm{U}$ : uracil, $\mathrm{T}$ : thymine, $\mathrm{C}$ : cytosine, $\mathrm{G}$ : guanine, $\mathrm{A}$ : adenine

た.この $0 \sim 9 \mathrm{~cm}$ 層での著しい核酸塩基量の減少は, 同試料で見られた全有機態炭素・窒素の鉛直分布とよく 一致するものであった，又，6種の核酸塩基類中ではウ
ラシルの減少割合が他の塩基よりも大きい. 更に $9 \mathrm{~cm}$ 付近より, 全核酸塩基量の減少割合が緩やかになるが, そのなかでもアデニンとグアニンの減少割合が特に緩や かになっているのが認められた。

\section{交献}

1）服部明彦編：“海洋生化学”， p. 68 (1973)，（東 京大学出版会).

2) 岡市友利: 海と空，56，39 (1980).

3) W. Van der Velden, A. W. Schwartz : Environ. Biogeochem., 1, 175 (1976).

4) W. Van der Verden, A. W. Schwartz : Chem. Geol., 18, 278 (1976).

5) G. Dungworth, M. Thijssen, J. Zuurveld, W. Van der Velden, A. W. Schwartz : Chem. Geol., 19, 275 (1977).

6) 新井健一, 斎藤恒行：日本水産学会誌, 29, 168 (1963).

$$
\text { 这 }
$$

High performance liquid chromatographic determination of nucleic acid bases in marine environmental samples. Shigeru Montani, Kunio TADA* and Tomotoshi OKAICHI (Faculty of Agriculture, Kagawa University, Miki-cho, Kido-gun, Kagawa 76107; *Present address : Research Institute of North Pacific Fisheries, Faculty of Fisheries, Hokkaido University, 3-1-1, Minatomachi, Hakodate-shi, Hokkaido 041)

Purines and pyrimidines are major chemical components of organisms. These bases are thought to play an important role on marine ecosystem and organic geochemistry. Therefore, cleanup procedures were developed for the determination of these bases in marine environmental samples. The separation and determination methods of uracil, thymine, cytosine, adenine, guanine and hypoxanthine were developed by HPLC using cation exchange mode. The present methods were rapid and convenient, as compared with those previously used. The data obtained as total purines and pyrimidines varied from 0.3 to 9.3 $\mu \mathrm{g} / \mathrm{l}$ for suspended particles in seawater and 4 to 54 $\mu \mathrm{g} / \mathrm{g}$ for sediment core samples obtained from HarimaNada of Seto Inland Sea in Japan.

(Received March 4, 1986)

\section{Keyword phrases}

cleanup procedures for marine environmntal samples; HPLG in cation determination mode; purines and pyrimidines in sediment core samples by HPLC; uracil, thymine, cytosine, adenine, guanine, hypoxantine. 